\title{
Drought induces oxidative stress in pea plants
}

\author{
Jose F. Moran, Manuel Becana, Iñaki Iturbe-Ormaetxe, Silvia \\ Frechilla* $^{*}$ Robert V. Klucas ${ }^{\star *}$, Pedro Aparicio-Tejo*
}

Departamento de Nutrición Vegetal, Estación Experimental de Aula Dei, CSIC, Apdo. 202, E-50080 Zaragoza, Spain

Received: 21 December 1993 / Accepted

April 1994

Name and address for correspondence:

Dr. M. Becana

Estación Experimental de Aula Dei

Apdo. 202

50080 Zaragoza

Spain

Phone \# +34-76-576511 ext. 217

FAX\# +34-76-575620

Abbreviations: $\quad \mathrm{ASC}=$ ascorbate; $\mathrm{DW}=$ dry weight; $\mathrm{DHA}=$ dehydroascorbate; $\mathrm{GSH}=$ reduced glutathione; $\mathrm{GSSG}=$ oxidized glutathione; $\mathrm{MDHA}=$ monodehydroascorbate (ascorbate free radical); TBARS=2-thiobarbituric-reactive substances; SOD $=$ superoxide dismutase; $\Psi_{\mathrm{w}}=$ water potential

*Permanent address: Dpto. de Ciencias del Medio Natural, E.T.S. de Ingenieros Agrónomos, Universidad Pública de Navarra, 31006 Pamplona, Spain

${ }^{* *}$ Permanent address: Dept. of Biochemistry, University of Nebraska, Lincoln, NE 68583, USA

Correspondence to: M. Becana; FAX: 34(76)575620 
Abstract. Pea (Pisum sativum L. cv. Frilene) plants subjected to drought (leaf water potential of $\approx-1.3 \mathrm{MPa}$ ) showed major reductions in photosynthesis $(78 \%)$, transpiration (83\%), and glycolate oxidase (EC 1.1.3.1) activity (44\%), and minor reductions $(\approx 18 \%)$ in the contents of chlorophyll $a$, carotenoids, and soluble protein. Water stress also led to pronounced decreases (72-85\%) in the activities of catalase (EC 1.11.1.6), dehydroascorbate reductase (EC 1.8.5.1), and glutathione reductase (EC 1.6.4.2), but resulted in the induction (32-42\%) of nonspecific peroxidase (EC 1.11.1.7) and superoxide dismutase (EC 1.1.5.1.1). Ascorbate peroxidase (EC 1.11.1.11) and monodehydroascorbate reductase (EC 1.6.5.4) activities decreased only by $15 \%$ and the two enzymes were acting in a cyclic manner for removing $\mathrm{H}_{2} \mathrm{O}_{2}$, which did not accumulate in stressed leaves. Drought had no effect on the levels of ascorbate and oxidized glutathione in leaves, but caused a $25 \%$ decrease in the content of reduced glutathione and a $67 \%$ increase in that of vitamin $\mathrm{E}$. In leaves, average concentrations of catalytic Fe, i.e. Fe capable of catalyzing free radical generation by redox cycling, were estimated as 0.7 to $7 \mu \mathrm{M}$ (well-watered plants, depending on age) and $16 \mu \mathrm{M}$ (water-stressed plants); those of catalytic $\mathrm{Cu}$ were $\approx 4.5 \mu \mathrm{M}$ and $18 \mu \mathrm{M}$, respectively. Oxidation of lipids and proteins from leaves was enhanced 2- to 3-fold under stress conditions and both processes were highly correlated. Fenton systems composed of the purported concentrations of ascorbate, $\mathrm{H}_{2} \mathrm{O}_{2}$, and catalytic metal ions in leaves produced hydroxyl radicals, peroxidized membrane lipids, and oxidized leaf proteins. It is proposed that augmented levels and decompartmentation of catalytic metals occurring during water stress are responsible for the oxidative damage observed in vivo.

Key words: Antioxidants - Free radicals - Oxidative damage - Plant senescence Water stress

Running title: J.F. Moran et al.: Activated oxygen in water-stressed pea leaves 


\section{Introduction}

Oxygen toxicity is an inherent feature of aerobic life. Photosynthetic plant cells are especially at risk for oxidative damage due to its oxygenic condition and to the abundance of photosensitizers and polyunsaturated fatty acids in the chloroplast envelope and thylakoids (Halliwell and Gutteridge 1989). Thus, it has been estimated that $1 \%$ of the oxygen consumed by plants is diverted to produce activated oxygen (Asada and Takahashi 1987) in various subcellular loci (Elstner 1987; Del Río et al. 1992). Hydrogen peroxide $\left(\mathrm{H}_{2} \mathrm{O}_{2}\right)$ and superoxide radical $\left(\mathrm{O}_{2}^{-}\right)$ are formed by the electron transport systems of chloroplasts and mitochondria, and by many flavin-dependent oxidases, including glycolate oxidase of peroxisomes (Del Río et al. 1992). $\mathrm{H}_{2} \mathrm{O}_{2}$ and $\mathrm{O}_{2}-$ also originate by nonenzymatic mechanisms such as the Fe-catalyzed oxidation of $\mathrm{NAD}(\mathrm{P}) \mathrm{H}$, reduced glutathione $(\mathrm{GSH})$, and ascorbate (ASC). $\mathrm{H}_{2} \mathrm{O}_{2}$ can inactivate various Calvin cycle enzymes (Asada and Takahashi 1987) and is involved in metal-catalyzed oxidation systems, marking proteins for degradation (Levine et al. 1990; Pacifici and Davies 1990; Stadtman and Oliver 1991). $\mathrm{O}_{2}-$ can directly inactivate some enzymes and interact with $\mathrm{H}_{2} \mathrm{O}_{2}$ to form hydroxyl radical $(\cdot \mathrm{OH})$ in the presence of trace amounts of $\mathrm{Fe}$ or $\mathrm{Cu}$ (Halliwell and Gutteridge 1989). This radical can oxidize virtually all types of molecules at nearly diffusion-controlled rates. Another highly reactive oxygen species, singlet oxygen $\left({ }^{1} \Delta \mathrm{gO}_{2}\right)$, is mainly formed by photodynamic reactions within the chloroplasts (Asada and Takahashi 1987; Elstner 1987).

Plants are endowed with an array of enzymes and small molecules to cope with free radicals. Superoxide dismutases (SOD) catalyze the dismutation of $\mathrm{O}_{2}^{-}$to $\mathrm{H}_{2} \mathrm{O}_{2}$ and $\mathrm{O}_{2}$, whereas catalase and nonspecific peroxidases destroy $\mathrm{H}_{2} \mathrm{O}_{2}$. The enzymes ASC peroxidase, dehydroascorbate (DHA) reductase, and oxidized glutathione (GSSG) reductase participate in the Halliwell-Asada pathway, which 
removes $\mathrm{H}_{2} \mathrm{O}_{2}$ in cyanobacteria, chloroplasts, and root nodules (Dalton et al. 1986). Monodehydroascorbate (MDHA) reductase, an enzyme that appears to be ubiquitous in plants, reduces MDHA back to ASC using NAD(P)H (Asada and Takahashi 1987; Dalton et al. 1992). The enzyme of chloroplasts uses preferentially NADH over NADPH (Asada and Takahashi 1987). Small antioxidants include ASC, $\mathrm{GSH}$, carotenoids, and vitamin E.

Oxidative stress ensues when the defensive capacity of the plant is overwhelmed by the formation of free radicals and other prooxidants. Increased free radical production has been implicated in aging, accelerated spoiling of cut flowers, fruit ripening, plant response to wounding and pathogen attack, and damage of plants by xenobiotics or stress conditions (Elstner 1987; Thompson et al. 1987; Bowler et al. 1992). $\mathrm{O}_{2}$ - production is enhanced in membranes from aging (Thompson et al. 1987) or stressed (Price and Hendry 1991; Del Río et al. 1992) plant tissues, whereas $\mathrm{OH}$ production has been detected in plants treated with paraquat (Babbs et al. 1989) or prolonged darkness (Becana and Klucas 1992). Unfortunately, many studies aimed at demonstrating a causative relation between free radicals and senescence have provided only circumstantial evidence, based on the behavior of a few enzymes or metabolites. Quite often, these studies involved extracts and assays in nonoptimized media or with techniques lacking essential controls.

Demonstration of oxidative stress in biological systems requires the quantification of antioxidant defenses, prooxidant factors, and oxidative damage to important molecules. We have conducted a comprehensive study on these parameters to find out whether drought induces oxidative stress in pea plants. 


\section{Materials and methods}

Chemicals and biochemicals. Organic solvents and inorganic acids were analytical or high-performance liquid chromatography (HPLC) grade from Panreac (Barcelona, Spain). All other chemical and biochemicals were of the highest quality available from Sigma (St. Louis, Mo., USA) or Aldrich (Milwaukee, Wis., USA), except $\mathrm{TiCl}_{4}$ and $\mathrm{NH}_{4} \mathrm{OH}$, which were purchased from Fluka (Buchs, Switzerland). Chelex-100 (200-400 mesh, $\mathrm{Na}^{+}$form) resin was obtained from Bio-Rad (Richmond, Cal., USA). Single-distilled water was used for preparing the nutrient solutions, and ultrapure (Milli-Q) water (Millipore, Milford, Mass., USA) was used for all other purposes.

Plant growth and drought treatment. Pea (Pisum sativum L. cv. Frilene, SENASA, Navarra) plants were grown in pots containing perlite/vermiculite (Becana and Klucas 1992) in a controlled environment chamber at $25 / 20^{\circ} \mathrm{C}$ (day/night), $60-70 \%$ relative humidity, $300 \mathrm{~mol} \cdot \mathrm{m}^{-2} \cdot \mathrm{s}^{-1}$, and 16-h photoperiod. Composition of the nutrient solution was as indicated previously (Becana and Klucas 1992) supplemented with $10 \mathrm{mM} \mathrm{KNO}_{3}$. After $30 \mathrm{~d}$ of growth, pots were separated at random into four groups: initial and final controls, drought, and recovery. Drought was induced in plants by withholding irrigation until a leaf water potential $\left(\Psi_{\mathrm{w}}\right)$ between -1.20 and $-1.45 \mathrm{MPa}$ was attained ( $\approx 10 \mathrm{~d}$ later). Recovery was by reirrigation with deionized water for $2 \mathrm{~d}$. Plants that served as final controls were maintained in optimal water conditions until harvest, which took place one day later than the harvest of plants used for recovery. All plants were at the late vegetative stage when harvested. Leaves (excluding petioles) were harvested two hours after the commencement of the photoperiod, frozen immediately in liquid $\mathrm{N}_{2}$, and kept at $-80^{\circ} \mathrm{C}$ until used. 
Physiological parameters. Two hours after starting the photoperiod, $\Psi_{\mathrm{w}}$ and osmotic potential were measured in the same leaves with a pressure chamber (Soil Moisture Equipment, Santa Barbara, Cal., USA) and a vapor pressure osmometer 5500 (Wescor, Logan, Ut., USA), respectively. Photosynthesis, stomatal resistance, and transpiration were determined with a LI-6200 portable photosynthesis system equipped with a LI-6250 $\mathrm{CO}_{2}$ analyzer (Li-COR, Lincoln, Neb., USA). Chlorophyll a, chlorophyll $b$, and total carotenoids were determined in acetone extracts (Lichtenthaler 1987).

Enzymatic activities. Enzymes were extracted at $0-4^{\circ} \mathrm{C}$ from $0.5 \mathrm{~g}$ leaves, using a mortar and pestle, with $50 \mathrm{mg}$ polyvinylpyrrolidone (PVP-10) and 5 or $10 \mathrm{ml}$ of the following optimized media. Glycolate oxidase: $100 \mathrm{mM} \mathrm{K-phosphate} \mathrm{(pH} \mathrm{8.3),} 1 \mathrm{mM}$ EDTA, $10 \mathrm{mM}$ glycolate, $100 \mathrm{M}$ FMN, $10 \mathrm{mM}$ cysteine. Catalase, nonspecific peroxidase, and DHA reductase: $100 \mathrm{mM}$ K-phosphate $(\mathrm{pH} 7.0), 0.1 \mathrm{mM}$ EDTA. ASC peroxidase: 50 mM K-phosphate ( $\mathrm{pH} 7.8$ ), $1 \mathrm{mM}$ ASC. MDHA reductase and GSSG reductase: 50 mM K-phosphate ( $\mathrm{pH} 7.8), 0.2 \mathrm{mM}$ EDTA, $10 \mathrm{mM}$ 2mercaptoethanol. SOD: $100 \mathrm{mM}$ K-phosphate ( $\mathrm{pH} 7.8), 0.1 \mathrm{mM}$ EDTA, $0.1 \%$ (v/v) Triton X-100.

Extracts were filtered through one layer of Miracloth (Calbiochem, San Diego, Cal., USA), centrifuged $(15,000 \cdot \mathrm{g}, 20 \mathrm{~min})$, and the supernatants used for the assays. Glycolate oxidase (Baker and Tolbert 1966), catalase (Aebi 1984), nonspecific peroxidase (Pütter 1974), ASC peroxidase (Asada 1984), MDHA reductase (Dalton et al. 1992), GSSG reductase (Dalton et al. 1986), and DHA reductase (Nakano and Asada 1981) were assayed according to published protocols. Total activity and isoenzymes of SOD were determined as indicated previously, using KCN (3 mM) as inhibitor (Becana et al. 1989). 
K-phosphate and Tris. $\mathrm{HCl}$ buffers, and ASC used for assays of ASC peroxidase and MDHA reductase were treated with Chelex resin $\left(\mathrm{Na}^{+}\right.$form). Enzyme activities were corrected for nonenzymatic rates and for interfering oxidases (Nakano and Asada 1981; Asada 1984; Dalton et al. 1986). Boiled enzymes gave no detectable activities. All enzymes were measured at $25^{\circ} \mathrm{C}$ with a Lambda-16 UV-visible spectrophotometer (Perkin-Elmer, Norwalk, Conn., USA) as initial activities (2 or 4 min), with no lag period or with a lag of 40 to $60 \mathrm{~s}$ (peroxidases). Protein was quantified by the dye-binding microassay (Bio-Rad).

Small molecules. ASC was extracted at $0^{\circ} \mathrm{C}$ from $0.5 \mathrm{~g}$ leaves with $5 \mathrm{ml}$ of $5 \%(\mathrm{w} / \mathrm{v})$ metaphosphoric acid, and GSH and GSSG with 5\% (w/v) sulfosalicylic acid. These antioxidants were quantified essentially as described by Law et al. (1983). Vitamin E ( $\alpha$-tocopherol) was extracted from $1 \mathrm{~g}$ leaves by using sequentially isopropanol, containing $1 \%(\mathrm{w} / \mathrm{v})$ pyrogallol, and chloroform (Laidman et al. 1971), and its concentration was determined by HPLC (System Gold, Beckman) on a $\mathrm{C}_{18}$ column (4.6 $\times 250 \mathrm{~mm}, 5 \mathrm{~m}$, Ultrasphere) using isocratic elution with 95\% methanol at 2 $\mathrm{ml} \cdot \mathrm{min}^{-1}$.

$\mathrm{H}_{2} \mathrm{O}_{2}$ was measured by reacting the $\mathrm{Ti}^{4+}\left[\mathrm{H}_{2} \mathrm{O}_{2}\right]$ complex with 4-(2pyridylazo)resorcinol, using catalase-treated samples as blanks (MacRae and Ferguson 1985). Because ASC in the samples was found to interfere with $\mathrm{H}_{2} \mathrm{O}_{2}$ determination, calibration curves for $\mathrm{H}_{2} \mathrm{O}_{2}$ were constructed in the presence of the ASC concentrations measured for all treatments (initial and final controls, drought, and recovery).

For assays of $\mathrm{Fe}$ and $\mathrm{Cu}$, leaves $(0.5 \mathrm{~g})$ were extracted with $6 \mathrm{ml}$ of Chelextreated $25 \mathrm{mM}$ K-phosphate $(\mathrm{pH}$ 7.0) and the homogenate was centrifuged $(15,000 \cdot \mathrm{g}, 20 \mathrm{~min})$ and further fractionated using Centricon-3 membranes (Amicon, Beverly, Mass., USA). Fe and $\mathrm{Cu}$ in the low molecular mass fraction were quantified 
using an atomic absorption spectrophotometer (AA-670G) with graphite furnace atomizer (Shimadzu, Kyoto, Japan).

Oxidative damage in vivo. Oxidative damage to lipids was estimated as the content of total 2-thiobarbituric-reactive substances. These were extracted from $0.5 \mathrm{~g}$ leaves with $5 \mathrm{ml}$ of $5 \%(\mathrm{w} / \mathrm{v})$ metaphosporic acid, and their concentration was determined (Aruoma et al. 1989) and expressed as equivalents of malondialdehyde (Halliwell and Gutteridge 1989). Oxidative damage to proteins was estimated as the content of carbonyl groups (Levine et al. 1990). Leaves $(0.5 \mathrm{~g})$ were homogenized with $5 \mathrm{ml}$ of $100 \mathrm{mM}$ K-phosphate ( $\mathrm{pH}$ 7.0) containing $1 \mathrm{mM}$ EDTA and $2.5 \mathrm{~g}$ each of the protease inhibitors aprotinin, leupeptin, and pepstatin A. The homogenate was clarified by centrifugation, the supernatant was freed from contaminating nucleic acids by treatment with streptomycin, and the protein carbonyl content was determined by reaction with 2,4-dinitrophenyl-hydrazine (Levine et al. 1990).

Oxidative damage in vitro. Production of $\cdot \mathrm{OH}$ in vitro was assessed by the deoxyribose degradation assay (Halliwell and Gutteridge 1989) as follows. The reaction mixtures $(1 \mathrm{ml})$ contained $10 \mathrm{mM}$ Na-phosphate $(\mathrm{pH} 7.4), 50 \mathrm{mM} \mathrm{NaCl}, 30$ $\mathrm{mM}$ deoxyribose, and a Fenton system comprising of $\mathrm{Fe}^{3+}\left(\mathrm{FeCl}_{3}\right), \mathrm{Cu}^{2+}\left(\mathrm{CuCl}_{2}\right)$, $\mathrm{H}_{2} \mathrm{O}_{2}$, and ASC at the estimated average concentrations in leaves. Solutions of $\mathrm{Fe}^{3+}$ and $\mathrm{Cu}^{2+}$ were prepared just before use in $\mathrm{HCl}$-acidified water, and those of $\mathrm{NaP}_{\mathrm{i}}, \mathrm{NaCl}$, and $\mathrm{ASC}$ were treated with Chelex. Reactions proceeded at $25^{\circ} \mathrm{C}$ for 5 min. The chromogen was extracted with 1-butanol and determined spectrophotometrically (Aruoma et al. 1989).

For measuring lipid peroxidation, microsomal membranes were extracted from $5 \mathrm{~g}$ of young leaves with $25 \mathrm{ml}$ of ice-cold $25 \mathrm{mM}$ Na-phosphate (pH 7.4), which was previously treated with Chelex and sparged with $\mathrm{N}_{2}$. The homogenate was 
filtered through one layer of Miracloth and the filtrate was centrifuged at $15,000 \cdot \mathrm{g}$ for $20 \mathrm{~min}$ and at 130,000.g for $1 \mathrm{~h}$. Lipid micelles were obtained by gently resuspending the pellet in $2.5 \mathrm{ml}$ of Chelex-treated, $\mathrm{N}_{2}$-purged phosphate-saline buffer [25 mM Na-phosphate ( $\mathrm{pH} 7.4), 150 \mathrm{mM} \mathrm{NaCl}$. The reaction mixtures $(1 \mathrm{ml})$ were composed of $10 \mathrm{mM}$ Na-phosphate ( $\mathrm{pH} 7.4)$, microsomes (125 $\mu \mathrm{g}$ protein), and the Fenton system indicated above. After incubating the samples at $25^{\circ} \mathrm{C}$ for 1 h, the chromogen was produced (Aruoma et al. 1989) and quantified by fluorescence (Halliwell and Gutteridge 1989).

Protein damage was estimated by the carbonyl assay (Levine et al. 1990). Leaf soluble proteins were extracted as described for measuring protein oxidative damage in vivo. After centrifugation at $15,000 \cdot \mathrm{g}$ for $20 \mathrm{~min}$ and at $130,000 \cdot \mathrm{g}$ for 1 $\mathrm{h}$, the supernatant was exhaustively dialyzed against $5 \mathrm{mM}$ K-phosphate $(\mathrm{pH} 7.0)$ and used as the protein source. The reaction mixture $(1.5 \mathrm{ml})$ contained $10 \mathrm{mM} \mathrm{K}$ phosphate $(\mathrm{pH} 7.3), 50 \mathrm{mM} \mathrm{NaN}_{3}, 1 \mathrm{mg}$ protein, and $\mathrm{Fe}^{2+}\left(\mathrm{FeSO}_{4}\right), \mathrm{Cu}^{+}\left(\mathrm{Cu}_{2} \mathrm{Cl}_{2}\right)$, and $\mathrm{H}_{2} \mathrm{O}_{2}$ at the average concentrations found in leaves. This Fenton system avoided the use of ASC, which interfered with the carbonyl assay. Solutions of $\mathrm{Fe}^{2+}$ and $\mathrm{Cu}^{+}$were prepared just before use in $\mathrm{N}_{2}$-saturated, $\mathrm{HCl}$-acidified water. After incubating at $37^{\circ} \mathrm{C}$ for $1 \mathrm{~h}, 0.5 \mathrm{ml}$ of $25 \% \mathrm{HCl}$ was added, and protein carbonyls were determined (Levine et al. 1990).

\section{Results and discussion}

Leaf water and carbon status. Water was withheld from pea plants until a moderate, physiologically relevant stress (leaf $\Psi_{\mathrm{w}}$ of $\approx-1.3 \mathrm{MPa}$ ) was reached, and then plants were allowed to recover by reirrigation. Plants used as final controls were $\approx 10$ $\mathrm{d}$ older than the initial controls but had the same age as plants that were subjected 
to stress. This enabled us to readily discriminate the effects of drought and normal aging upon the various parameters. At the level of stress applied in our experiment, leaf turgor potential was virtually zero but regained the control value after two days of reirrigation; under these conditions, leaf $\Psi_{\mathrm{w}}$ also recovered and the osmotic potential was very close to the final control value (Table 1). In many plants the decline of $\mathrm{CO}_{2}$ assimilation starts when leaf turgor potential is almost nil (Farquhar and Sharkey 1982). Indeed, water stress caused a $\approx 80 \%$ reduction of photosynthesis and transpiration, and a 10-fold increase of stomatal resistance. Water deprivation also led to a $44 \%$ decrease in glycolate oxidase activity, a key enzyme of the photorespiratory process (Table 1). This inhibition, along with the drastic decline $(78 \%)$ in catalase activity (Table 2 ), probably reflects a general deterioration of peroxisomes under water stress. However, the content of chlorophyll $b$ remained constant and that of chlorophyll $a$ and soluble protein decreased only by 18 to $20 \%$ (Table 1 ). These observations rule out any serious photooxidative damage and indicate that the concentration of photosynthetic pigments is not limiting $\mathrm{CO}_{2}$ assimilation. The lack of significant lesions to the photosynthetic machinery is supported by the almost complete recovery $(82 \%)$ of the photosynthetic rates after reirrigation (Table 1).

Antioxidants and prooxidants. Catalase, the enzyme responsible for eliminating $\mathrm{H}_{2} \mathrm{O}_{2}$ in the peroxisomes, and DHA reductase and GSSG reductase, two key enzymes of the Halliwell-Asada pathway for the removal of $\mathrm{H}_{2} \mathrm{O}_{2}$ in the chloroplasts, were largely (72 to $85 \%$ ) depressed by water stress (Table 2). In contrast, ASC peroxidase and MDHA reductase activities declined only by $15 \%$. Despite all these changes, $\mathrm{H}_{2} \mathrm{O}_{2}$ did not accumulate in stressed leaves (Fig. 1). This is explained considering that: (i) glycolate oxidase activity, a main source of $\mathrm{H}_{2} \mathrm{O}_{2}$ in leaves (Asada and Takahashi 1987), decreased by 44\% (Table 1); (ii) $\mathrm{H}_{2} \mathrm{O}_{2}$ is being used in metal-catalyzed reactions, such as lipid and protein oxidation (see Fig. 2); and (iii) 
$\mathrm{H}_{2} \mathrm{O}_{2}$ is being removed by ASC peroxidase and MDHA reductase acting in a cyclic manner. Thus, the MDHA formed by ASC peroxidase is reduced back to ASC by MDHA reductase at the expense of $N A D(P) H$. The functioning of this cycle is strongly supported by the high correlation observed between the activities of MDHA reductase and ASC peroxidase $(r=0.95, P=0.05)$, and by the constancy of ASC concentration in leaves during stress (Table 2). In addition to MDHA reductase of the chloroplast stroma, Miyake and Asada (1992) have recently reported that ASC may be regenerated also at the thylakoid level by direct photoreduction of MDHA.

The relative contribution of DHA reductase and MDHA reductase in the regeneration of the ASC required for the disposal of $\mathrm{H}_{2} \mathrm{O}_{2}$ is unclear (Bowler et al. 1992), but Asada and Takahashi (1987) have surmised that DHA reductase would participate only in ASC regeneration when MDHA reductase activity is limited by the availability of $\mathrm{NAD}(\mathrm{P}) \mathrm{H}$. The coupling of $\mathrm{ASC}$ peroxidase and MDHA reductase, the lack of $\mathrm{H}_{2} \mathrm{O}_{2}$ accumulation, and the maintenance of ASC concentration in leaves, despite the $85 \%$ inhibition of DHA reductase, demonstrate that (i) MDHA reductase is a key detoxifying enzyme under stress conditions; and (ii) spontaneous disproportionation of MDHA into ASC and DHA is negligible in the presence of an active MDHA reductase.

The effect of water deficit on the concentrations of $A S C$ and $\mathrm{H}_{2} \mathrm{O}_{2}$ in leaves has been also investigated in other plants, but the stress applied (Mukherjee and Choudhuri 1983) was much more severe than in our study. Likewise, $\mathrm{H}_{2} \mathrm{O}_{2}$ concentrations were reported to increase in plants subjected to drought (Mukherjee and Choudhuri 1983; Chowdhury and Choudhuri 1985; Irigoyen et al. 1992). In all these cases, the technique used was not specific for $\mathrm{H}_{2} \mathrm{O}_{2}$ since it was based on the reaction of $\mathrm{Ti}^{4+}$ with hydroperoxides, and blanks containing catalase were not included. Their observations most likely result from increases in the content of lipid hydroperoxides (lipid peroxidation) rather than in that of $\mathrm{H}_{2} \mathrm{O}_{2}$. 
Nonspecific (guaiacol) peroxidase and SOD activities, expressed on a dry weight (DW) basis, remained unchanged in water stressed leaves (Table 2) but increased by $32 \%$ and $42 \%$, respectively, when expressed as specific activities. Both types of enzymes are responsive to a range of environmental stresses, including drought (Buckland et al. 1991; Bowler et al. 1992). Pea leaves contain two different SOD isozymes having $\mathrm{Cu}$ plus $\mathrm{Zn}$ or $\mathrm{Mn}$ as prosthetic metals. The CuZn-isozyme is located in the cytosol and chloroplast stroma and the Mn-isozyme in the mitochondria and, less abundantly, in the peroxisomes (Del Río et al. 1992). The relative proportion of the two types of isozymes was markedly affected by drought and aging (Table 2). CuZn-SOD activity was higher in water-stressed plants (50\% versus $30 \%$ ) and Mn-SOD activity in the older plants (70\% versus $44 \%)$. Because chloroplastic SOD is the predominant CuZn-isoenzyme in green leaves (Bowler et al. 1992), the increase of CuZn-SOD activity with drought, from $\approx 1.3$ to 3 units. min $^{-1}$ (mg protein $)^{-1}$, may reflect enhanced $\mathrm{O}_{2}^{-}$production in the chloroplasts (Thompson et al. 1987; Price and Hendry 1991), probably as a result of restricted $\mathrm{CO}_{2}$ supply and augmented leakage of electrons from photosystems onto $\mathrm{O}_{2}$.

Although GSSG reductase was lowered by $\approx 70 \%$, high levels of total glutathione [2.24 to $2.95 \mathrm{~mol} \cdot \mathrm{g} \mathrm{DW}^{-1}$ ] and $\mathrm{GSH}$ (>85\% of total glutathione) were maintained during water stress (Table 2). Our results indicate that (i) the $25 \%$ loss of GSH was not attributable to its oxidation to GSSG; (ii) the levels of GSH and GSSG are tightly regulated; and (iii) alternative routes to GSSG reductase must exist in stressed leaves to keep a high GSH/GSSG ratio, such as de novo synthesis by glutathione synthetase. In fact, leaf chloroplasts are likely the main site for glutathione synthesis within the plant (Bielawski and Joy 1986). Working with a drought-tolerant moss, Dhindsa (1991) found a correlation between GSSG content and lipid peroxidation, and proposed to use the level of GSSG as an index of oxidative stress. Our determinations of GSSG (Table 2) and lipid peroxidation (Fig. 2) are not consistent with that proposal. 
Carotenoids and vitamin E (especially -tocopherol) are the main lipid-soluble antioxidants of plant cells. Carotenoid concentration decreased only $18 \%$, whereas that of vitamin $E$ increased $66 \%$ in stressed leaves (Table 2). Carotenoids protect against photooxidation because they actively quench ${ }^{1} \Delta \mathrm{gO}_{2}$ and minimize its formation by absorbing excess energy from excited triplet states of chlorophyll. The small decrease in carotenoid content indicates that photooxidative damage was not important under the moderate irradiance and water stress conditions used in our experiment. Drought-enhanced synthesis of vitamin E has been observed in leaves of a number of grasses (Price and Hendry 1989), but not in mosses (Seel et al. 1992) or in several other higher plants (Buckland et al. 1991). Since vitamin $E$ is a powerful inhibitor of the propagation step of lipid peroxidation (Halliwell and Gutteridge 1989), the synthesis of vitamin E under stress probably represents a response of the plant to augmented free radical production at the membrane level.

Transition metals are a stringent requirement for $\mathrm{H}_{2} \mathrm{O}_{2}$-dependent $\cdot \mathrm{OH}$ radical production (Halliwell and Gutteridge 1989). The contents of $\mathrm{Fe}$ and $\mathrm{Cu}$ in the low molecular mass fraction of leaf cytosol, which represent catalytic $\mathrm{Fe}$ and catalytic $\mathrm{Cu}$, increased 1.5- and 2.5-fold, respectively, under water stress (Fig. 1). There was virtually no catalytic Fe in young plants but levels of $2.6 \mathrm{~g} \cdot \mathrm{g} \mathrm{DW}^{-1}$ were measured in old plants. In contrast, the concentration of catalytic $\mathrm{Cu}$ did not vary with plant age and was of the same order of magnitude as that of catalytic Fe (Fig. 1). Upon reirrigation of plants, the levels of catalytic $\mathrm{Cu}$ returned to the control values but those of catalytic Fe further increased to 2.5-fold over the control (Fig. 1). Price and Hendry (1991) have reported on the total content of several transition metals in wheat shoots and roots. Drought caused a rapid increase (within $6 \mathrm{~h}$ ) in the uptake of metals into the root and, two days later, into the shoots. It is not known, however, what proportion of the calculated amounts of metals is accounted for by catalytic $\mathrm{Fe}$ and $\mathrm{Cu}$, because the major part of $\mathrm{Fe}$ and $\mathrm{Cu}$ in tissues is bound to proteins in a 
form inactive for free radical generation (Asada and Takahashi 1987; Halliwell and Gutteridge 1989; Becana and Klucas 1992).

Oxidative damage in vivo. Membrane lipids and proteins are particularly vulnerable to attack by $\cdot \mathrm{OH},{ }^{1} \Delta \mathrm{gO}_{2}$, and other highly reactive oxygen species (Elstner 1987; Halliwell and Gutteridge 1989). Levels of lipid peroxidation in leaves increased 2.4fold with drought but still remained 2-fold greater than the control values upon reirrigation of plants for two days (Fig. 2). Increases in lipid peroxidation have been observed in senescing plants and result in augmented membrane fluidity, solute leakage, enhanced proteolysis, and loss of enzyme and receptor function (Thompson et al. 1987).

Oxidative damage to proteins has not been previously quantified in plants. In humans the amount of oxidized proteins increases 2- to 3-fold during normal aging and in premature aging diseases, such as progeria and Werner's syndrome (Stadtman and Oliver 1991). Water stress led to a similar increase (1.8-fold) in the level of oxidatively modified proteins in pea leaves. This level still remained $43 \%$ over the control after reirrigation (Fig. 2). Such a nearly doubling in the amount of damaged proteins accumulated in stressed leaves is certainly conducive to cellular metabolic impairment (Stadtman and Oliver 1991). Protein degradation, which follows oxidative modification of proteins (Levine et al. 1990; Pacifici and Davies 1990; Stadtman and Oliver 1991), has been proposed as a better index of oxidative stress than lipid peroxidation because the latter yields many different products and these only appear after a lag period (Pacifici and Davies 1990). We have found a very high correlation ( $r=0.98, P=0.02)$ between lipid and protein oxidation, indicating that both processes are intimately associated in stressed plants and can be considered as reliable markers of oxidative stress. 
Oxidative damage in vitro. Leaf cells contain all the ingredients required in Fenton chemistry, namely, suitable transition metal ions, $\mathrm{ASC}$, and $\mathrm{H}_{2} \mathrm{O}_{2}$. Catalytic Fe was not detectable in well-watered, young plants, but its concentration could be estimated as $7 \mu \mathrm{M}$ and $16 \mu \mathrm{M}$ in leaves of old plants and water-stressed plants, respectively. An analogy with what occurs in humans may be pertinent here: catalytic Fe was not detectable in plasma from healthy subjects but amounted to 1$10 M$ in several clinical conditions (Gutteridge 1991). These findings strongly suggest that the increased availability of catalytic metal ions for Fenton-like reactions is a causative factor of certain stress and pathological states observed in plant and animals, respectively. In these situations, catalytic metals may be released from metalloproteins by oxidative or proteolytic attack (Thompson et al. 1987; Halliwell and Gutteridge 1989). To substantiate this hypothesis, we have conducted several in vitro experiments using the average concentrations of ASC and $\mathrm{H}_{2} \mathrm{O}_{2}$ in leaves for each of the plant treatments, i.e. 1.4 to $2.2 \mathrm{mM}$ and $\approx 1 \mathrm{mM}$, respectively. These concentrations are in agreement with those reported for leaves (Nakano and Asada 1981; MacRae and Ferguson 1985) and root nodules (Dalton et al. 1986) of other plants.

Incubation of deoxyribose for 5 min with a Fenton system containing $\mathrm{Fe}^{3+}, \mathrm{Cu}^{2+}$, ASC, and $\mathrm{H}_{2} \mathrm{O}_{2}$, gave rise to large amounts of thiobarbituric-reactive material (Fig. 3), which indicated that $\mathrm{OH}$ was being produced at high rates (Gutteridge and Wilkins 1983; Halliwell and Gutteridge 1989). Deoxyribose degradation was 4- to 5fold lower in the absence of added $\mathrm{H}_{2} \mathrm{O}_{2}$ (data not shown), but it followed a similar pattern to that obtained with $\mathrm{H}_{2} \mathrm{O}_{2}$ (Fig. 3). Damage to deoxyribose was greater when both $\mathrm{Fe}^{3+}$ and $\mathrm{Cu}^{2+}$ were included than when $\mathrm{Cu}^{2+}$ was added alone. At similar concentrations of metal ions, more deoxyribose was degraded with $\mathrm{Cu}^{2+}$ than with $\mathrm{Fe}^{3+}$ (Fig. 3). The same conclusion was drawn using a different Fenton system (Gutteridge and Wilkins 1983). 
Peroxidation of membrane lipids from leaves was stimulated by $\mathrm{Fe}$ and $\mathrm{H}_{2} \mathrm{O}_{2}$, and, to a much lesser extent, by $\mathrm{Cu} \quad(\approx 30 \%$ of the rate with Fe in our conditions); however, $\mathrm{Cu}$ partially inhibited Fe-dependent lipid peroxidation (Fig. 4). The inhibitory effect of $\mathrm{Cu}$, despite its great potential to form $\cdot \mathrm{OH}$, clearly demonstrates that $\mathrm{OH}$ is not required for lipid peroxidation to proceed. This contention is supported by studies with $\cdot \mathrm{OH}$ scavengers (Halliwell and Gutteridge 1989; Becana and Klucas 1992). The inhibition by Cu may operate by a similar mechanism, as yet unknown, to that of $\mathrm{Pb}$ and $\mathrm{Al}$, which were reported as inhibitors of peroxidation in the same ASC-dependent system (Aruoma et al. 1989). On the other hand, the observation of Cu-dependent lipid peroxidation, in the apparent absence of $\mathrm{Fe}$, is at odds with the proposal that an $\mathrm{Fe}^{2+}: \mathrm{Fe}^{3+}$ complex initiates lipid peroxidation (reviewed by Halliwell and Gutteridge 1989).

Considerable oxidation of amino acid residues to carbonyl derivatives occurred upon incubation of leaf proteins with $\mathrm{Fe}^{2+}, \mathrm{Cu}^{+}$, and $\mathrm{H}_{2} \mathrm{O}_{2}$ (Fig. 4). When $\mathrm{H}_{2} \mathrm{O}_{2}$ was omitted, protein oxidation was only detectable, and at low rates, in the drought treatment (data not shown). Protein oxidation is thought to involve binding of metal ions to the proteins and subsequent site-specific attack by the $\cdot \mathrm{OH}$ arising from the metal-catalyzed decomposition of $\mathrm{H}_{2} \mathrm{O}_{2}$ (Stadtman and Oliver 1991). Our observations that (i) $\mathrm{H}_{2} \mathrm{O}_{2}$ is required for significant rates of $\cdot \mathrm{OH}$ production and protein oxidation, (ii) $\mathrm{Cu}$ was more effective than Fe in both cases, and (iii) the effects of both metals were approximately additive, are fully consistent with such a mechanism. The greater protein oxidation observed with $\mathrm{Cu}$ is attributable to its high and nonspecific affinity for amino groups in proteins (Gutteridge and Wilkins 1983).

In summary, drought causes an increase in the concentration of catalytic metals, which may become available for participating in Fenton-like reactions. The oxidative damage to lipids and proteins observed in leaves certainly indicates that $\cdot \mathrm{OH}$ and/or other equally powerful oxidants are being formed in vivo. Contrary to the widely held 
view, $\mathrm{Cu}$, and not only $\mathrm{Fe}$, may play a critical role in the toxicity of activated oxygen in stressed leaves.

We thank Dr. R. Picorel (E.E. de Aula Dei, CSIC) for allowing us access to HPLC equipment. J.F.M., I. I., and S.F. were the recipients of predoctoral fellowships from the Comunidades Autónomas de Aragón, País Vasco, and Navarra, respectively. R.V.K. thanks the U.S. Department of Agriculture (grant 91-37305-6705) for travel support. This work was financed by grants from the Comisión Interministerial de Ciencia y Tecnología (AGR-91-0857-C02 to P.A. and M.B.) and Dirección General de Investigación Científica y Técnica (PB92-0058 to M.B).

\section{References}

Aebi, H. (1984) Catalase in vitro. Methods Enzymol. 105, 121-126

Aruoma, O.I., Halliwell, B., Laughton, M.J., Quinlan, G.J. \& Gutteridge, J.M.C. (1989) The mechanism of initiation of lipid peroxidation. Evidence against a requirement for an iron (II)-iron (III) complex. Biochem. J. 258, 617-620

Asada, K. (1984) Chloroplasts: formation of active oxygen and its scavenging. Methods Enzymol. 105, 422-429

Asada, K. \& Takahashi, M. (1987) Production and scavenging of active oxygen in photosynthesis. In: Photoinhibition, pp. 227-287, Kyle, D.J., Osmond, C.B., Arntzen, C.J., eds. Elsevier, Amsterdam

Babbs, C.F., Pham, J.A., Coolbaugh, R.C. (1989) Lethal hydroxyl radical production in paraquat-treated plants. Plant Physiol. 90,1267-1270

Baker, A.L., Tolbert, N.E. (1966) Glycolate oxidase (ferredoxin-containing form). Methods Enzymol. 9, 338-342 
Becana, M., Paris, F.J., Sandalio, L.M. \& Del Río, L.A. (1989) Isoenzymes of superoxide dismutase in nodules of Phaseolus vulgaris L., Pisum sativum L., and Vigna unguiculata (L.) Walp. Plant Physiol. 90, 1286-1292

Becana, M., Klucas, R.V. (1992) Transition metals in legume root nodules: irondependent free radical production increases during nodule senescence. Proc. Natl. Acad. Sci. USA 89, 8958-8962

Bielawski, W., Joy, K.W. (1986) Reduced and oxidised glutathione and glutathionereductase activity in tissues of Pisum sativum. Planta 169, 267-272

Bowler, C., Van Montagu, M., Inzé, D. (1992) Superoxide dismutase and stress tolerance. Annu. Rev. Plant Physiol. Plant Mol. Biol. 43, 83-116

Buckland, S.M.,Price, A.H., Hendry. G.A.F. (1991) The role of ascorbate in droughttreated Cochlearia atlantica Pobed. and Armeria maritima (Mill.) Willd. New Phytol. 119, 155-160

Chowdhury, S.R., Choudhuri, M.A. (1985) Hydrogen peroxide metabolism as an index of water stress tolerance in jute. Physiol. Plant. 65, 476-480

Dalton, D.A., Russell, S.A., Hanus, F.J., Pascoe, G.A., Evans, H.J. (1986) Enzymatic reactions of ascorbate and glutathione that prevent peroxide damage in soybean root nodules. Proc. Natl. Acad. Sci. USA 83, 3811-3815

Dalton, D.A., Langeberg, L., Robbins, M. (1992) Purification and characterization of monodehydroascorbate reductase from soybean root nodules. Arch. Biochem. Biophys. 292, 281-286

Del Río, L.A., Sandalio, L.M., Palma, J.M., Bueno, P., Corpas, F.J. (1992) Metabolism of oxygen radicals in peroxisomes and cellular implications. Free Rad. Biol. Med. 13, 557-580

Dhindsa, R.S. (1991) Drought stress, enzymes of glutathione metabolism, oxidation injury, and protein synthesis in Tortula ruralis. Plant Physiol. 95, 648-651 
Elstner, E.F. (1987) Metabolism of activated oxygen species. In: The biochemistry of plants, pp. 253-315. Vol. 11. Davies, D.D., ed. Academic Press, San Diego

Farquhar, G.D., Sharkey, T.D. (1982) Stomatal conductance and photosynthesis. Annu. Rev. Plant Physiol. 33, 317-345

Gutteridge, J.M.C. (1991) Metalloproteins as donors of metal ions for oxygen chemistry. In: Oxidative damage and repair, pp. 355-363. Davies, K.J.A., ed. Pergamon, Oxford

Gutteridge, J.M.C., Wilkins, S. (1983) Copper salt-dependent hydroxyl radical formation damage to proteins acting as antioxidants. Biochim. Biophys. Acta $759,38-41$

Halliwell, B., Gutteridge, J.M.C. (1989) Free radicals in biology and medicine. 2nd edn. Clarendon, Oxford

Irigoyen, J.J., Emerich, D.W., Sánchez-Díaz, M. (1992) Alfalfa leaf senescence induced by drought stress: photosynthesis, hydrogen peroxide metabolism, lipid peroxidation and ethylene evolution. Physiol. Plant. 84, 67-72

Laidman, D.L., Gaunt, J.K., Hall, G.S., Broad, C.T. (1971) Extraction of tocopherols from plant tissues. Methods Enzymol. 18, 366-369

Law, M.Y., Charles, S.A., Halliwell, B. (1983) Glutathione and ascorbic acid in spinach (Spinacia oleracea) chloroplasts. Biochem. J. 210, 899-903

Levine, R.L., Garland, D., Oliver, C., Amici, A., Climent, I., Lenz, A., Ahn, B., Shaltiel, S., Stadtman, E.R. (1990) Determination of carbonyl content in oxidatively modified proteins. Methods Enzymol. 186, 464-478

Lichtenthaler, H.K. (1987) Chlorophylls and carotenoids: pigments of photosynthetic biomembranes. Methods Enzymol. 148, 350-382

MacRae, E.A., Ferguson, I.B. (1985) Changes in catalase activity and hydrogen peroxide concentration in plants in response to low temperature. Physiol. Plant. $65,51-56$ 
Miyake, C., Asada, K. (1992) Thylakoid-bound ascorbate peroxidase in spinach chloroplasts and photoreduction of its primary oxidation product monodehydroascorbate radicals in thylakoids. Plant Cell Physiol. 33, 541-553.

Mukherjee, S.P., Choudhuri, M.A. (1983) Implications of water stress-induced changes in the levels of endogenous ascorbic acid and hydrogen peroxide in Vigna seedlings. Physiol. Plant. 58, 166-170

Nakano, Y., Asada, K. (1981) Hydrogen peroxide is scavenged by ascorbatespecific peroxidase in spinach chloroplasts. Plant Cell Physiol. 22, 867-880

Pacifici, R.E., Davies, K.J.A. (1990) Protein degradation as an index of oxidative stress. Methods Enzymol. 186, 485-502

Price, A.H., Hendry, G.A.F. (1989) Stress and the role of activated oxygen scavengers and protective enzymes in plants subjected to drought. Biochem. Soc. Trans. 17, 493-494

Price, A.H., Hendry, G.A.F. (1991) Iron-catalysed oxygen radical formation and its possible contribution to drought damage in nine native grasses and three cereals. Plant Cell Environ. 14, 477-484

Pütter, J. (1974) Peroxidases. Methods Enzym. Anal. 2, 685-690

Seel, W.E., Hendry, G.A.F., Lee, J.A. (1992) Effects of dessication on some activated oxygen processing enzymes and anti-oxidants in mosses. J. Exp. Bot. 43, 1031-1037

Stadtman, E.R., Oliver, C.N. (1991) Metal-catalyzed oxidation of proteins. Physiological consequences. J. Biol. Chem. 266, 2005-2008

Thompson, J.E., Legge, R.L., Barber, R.F. (1987) The role of free radicals in senescence and wounding. New Phytol. 105, 317-344 
Table 1. Physiological status of leaves of pea plants subjected to drought. Plant treatments are designed as $I$, initial control; $D$, drought; $R$, recovery; $F$, final control. Values are means of 6-10 replicates, corresponding to independent plant samples. Means denoted by the same letter did not significantly differ at $P<0.01$ based on Duncan's multiple range test

\begin{tabular}{|c|c|c|c|c|c|c|c|}
\hline Parametera & I & & $\mathrm{D}$ & & $\mathrm{R}$ & & $\mathrm{F}$ \\
\hline Water potential & -0.34 & & -1.34 & $b$ & -0.50 & c & $-0.41 a c$ \\
\hline Osmotic potential & -0.89 & & -1.34 & b & -1.04 & c & $-0.94 a$ \\
\hline Turgor potential & 0.55 & & 0 & b & 0.54 & a & $0.53 a$ \\
\hline Water content & 88.5 & & 81.3 & b & 85.0 & c & $86.7 \mathrm{~d}$ \\
\hline Photosynthesis & 10.3 & & 2.4 & $b$ & 8.9 & c & 10.9 a \\
\hline Stomatal resistance & 0.98 & & 9.48 & $b$ & 1.78 & & 0.96 a \\
\hline Transpiration & 6.89 & & 1.26 & $\mathrm{~b}$ & 4.20 & & 7.42 a \\
\hline Glycolate oxidase & 17.4 & & 8.3 & $b$ & 8.1 & & $14.7 \mathrm{a}$ \\
\hline Chlorophyll a & 13.9 & & 9.5 & $\mathrm{~b}$ & 9.8 & bc & $11.7 \mathrm{c}$ \\
\hline Chlorophyll $b$ & 4.9 & & 3.7 & b & 3.5 & & $4.3 \mathrm{ab}$ \\
\hline Protein & 166 & & 104 & b & 97 & $b$ & $129 \mathrm{c}$ \\
\hline
\end{tabular}

aUnits of parameters: water, osmotic, and turgor potentials (MPa); water content $(\%)$; photosynthesis $\left(\mu \mathrm{mol} \mathrm{CO}_{2} \cdot \mathrm{m}^{-2} \cdot \mathrm{s}^{-1}\right)$; stomatal resistance (s. $\mathrm{cm}^{-1}$ ); transpiration (mmol $\mathrm{H}_{2} \mathrm{O} \cdot \mathrm{m}^{-2} \cdot \mathrm{s}^{-1}$ ); glycolate oxidase ( $\mu \mathrm{mol}$ glyoxylate. $\left.\min ^{-1} \cdot \mathrm{g} \mathrm{DW}^{-1}\right)$; chlorophyll $a$, chlorophyll $b$, and protein $(\mathrm{mg} \cdot \mathrm{g}$ $\left.\mathrm{DW}^{-1}\right)$. 
Table 2. Enzymes and small antioxidants in leaves of pea plants subjected to drought. Designation of plant treatments as for Table 1. Values are means of 4-8 replicates, corresponding to independent plant extracts. Means denoted by the same letter did not significantly differ at $P<0.01$ based on Duncan's multiple range test

\begin{tabular}{lrrrc}
\hline Parametera & I & D & R & F \\
\hline Catalase & $9.0 \mathrm{a}$ & $1.4 \mathrm{~b}$ & $3.9 \mathrm{c}$ & $6.3 \mathrm{~d}$ \\
Guaiacol peroxidase & $30.5 \mathrm{a}$ & $26.3 \mathrm{a}$ & $31.7 \mathrm{a}$ & $25.0 \mathrm{a}$ \\
ASC peroxidase & $79.8 \mathrm{a}$ & $62.1 \mathrm{~b}$ & $62.6 \mathrm{~b}$ & $73.5 \mathrm{a}$ \\
DHA reductase & $17.9 \mathrm{a}$ & $1.6 \mathrm{~b}$ & $5.4 \mathrm{c}$ & $10.6 \mathrm{~d}$ \\
MDHA reductase & $28.8 \mathrm{a}$ & $23.0 \mathrm{~b}$ & $20.5 \mathrm{~b}$ & $27.1 \mathrm{a}$ \\
GSSG reductase & $7.7 \mathrm{a}$ & $2.1 \mathrm{~b}$ & $4.4 \mathrm{c}$ & $7.5 \mathrm{a}$ \\
CuZn-SOD & $400 \mathrm{a}$ & $317 \mathrm{a}$ & $304 \mathrm{a}$ & $166 \mathrm{~b}$ \\
Mn-SOD & $315 \mathrm{a}$ & $317 \mathrm{a}$ & $329 \mathrm{a}$ & $387 \mathrm{~b}$ \\
ASC & $14.4 \mathrm{a}$ & $9.5 \mathrm{~b}$ & $7.9 \mathrm{~b}$ & $10.3 \mathrm{~b}$ \\
GSH & $2.38 \mathrm{ab}$ & $1.90 \mathrm{a}$ & $2.69 \mathrm{~b}$ & $2.52 \mathrm{~b}$ \\
GSSG & $0.35 \mathrm{a}$ & $0.34 \mathrm{a}$ & $0.46 \mathrm{a}$ & $0.43 \mathrm{a}$ \\
Carotenoids & $4.0 \mathrm{a}$ & $2.8 \mathrm{~b}$ & $2.9 \mathrm{bc}$ & $3.4 \mathrm{c}$ \\
Vitamin E & $0.74 \mathrm{a}$ & $1.20 \mathrm{~b}$ & $0.95 \mathrm{c}$ & $0.72 \mathrm{a}$
\end{tabular}

aUnits of enzymatic activity (in $\mathrm{min}^{-1} \cdot \mathrm{g} \mathrm{DW}^{-1}$ ): catalase $\left(\mathrm{mmol} \mathrm{H}_{2} \mathrm{O}_{2}\right.$ ), guaiacol peroxidase ( $\mu \mathrm{mol}$ guaiacol), ASC peroxidase and DHA reductase $(\mu \mathrm{mol}$ ASC), MDHA reductase $(\mu \mathrm{mol} \mathrm{NADH})$, GSSG reductase $(\mu \mathrm{mol}$ NADPH), and SOD (units). One unit of SOD was the amount of enzyme which inhibited the $\mathrm{O}_{2}{ }^{-}$-dependent reduction of ferricytochrome $c$ by $50 \%$ (Becana et al. 1989). Units of metabolites (in $\mathrm{g} \mathrm{DW}^{-1}$ ): ASC, GSH, GSSG, and vitamin $\mathrm{E}(\mu \mathrm{mol})$, carotenoids $(\mathrm{mg})$. 


\section{Legends for Figures:}

Fig. 1. Content of $\mathrm{H}_{2} \mathrm{O}_{2}$ and catalytic metals, $\mathrm{Fe}$ (.) and $\mathrm{Cu}$ ( ), in pea leaves subjected to drought. Plant treatments as for Table 1. Error bars represent $\pm S E(n=$ 4-8 replicates corresponding to different plant extracts).

Fig. 2. Oxidative damage to lipids ( ) and proteins ( ) in pea leaves subjected to drought. Plant treatments as for Table 1. Error bars represent $\pm S E(n=4-8$ replicates corresponding to different plant extracts). TBARS $=$ thiobarbituric acid-reactive substances; $\mathrm{C}=\mathrm{O}$, carbonyl groups.

Fig. 3. Deoxyribose degradation by reaction mixtures containing $\mathrm{ASC}, \mathrm{H}_{2} \mathrm{O}_{2}$, and $\mathrm{Fe}^{3+}\left(\mathrm{)}, \mathrm{Cu}^{2+}(\mathrm{)}\right.$ or both metal ions ( ) at the estimated average concentrations in pea leaves. Plant treatments as for Table 1. The whole experiment was repeated twice and values represent means of two replicates differing by less than $10 \%$. TBARS $=$ thiobarbituric acid-reactive substances.

Fig. 4. Lipid peroxidation and protein oxidation by reaction mixtures containing ASC, $\mathrm{H}_{2} \mathrm{O}_{2}$, and $\mathrm{Fe}^{3+}(), \mathrm{Cu}^{2+}(\quad)$ or both metal ions $(\quad)$ at the estimated average concentrations in pea leaves. In the absence of $\mathrm{H}_{2} \mathrm{O}_{2}$ only lipid peroxidation was detectable ( ). Plant treatments as for Table 1. The whole experiment was repeated twice and values represent means of two replicates differing by less than $10 \% . \mathrm{C}=\mathrm{O}$, carbonyl groups. 